\title{
Advances in the propagation of acerola
}

\author{
Rogério Ritzinger ${ }^{1}$, Cecilia Helena Silvino Prata Ritzinger ${ }^{2}$, \\ Nelson Fonseca ${ }^{3}$, Cristina de Fátima Machado ${ }^{4}$
}

Abstract - The acerola tree (Malpighia emarginata Sessé \& Moc. ex DC.) is a fruit species that has prospered in the Brazilian tropical regions, especially in the Northeast, thanks to the high content of vitamin $\mathrm{C}$ in the fruits, among other characteristics that make it attractive to the producer, such as early production. Although there is increasing demand for the product, the production of certified seedlings of good commercial varieties is still a barrier to further expansion of the crop. This review aims to present, in a comprehensive way, technical information on how the spread has been made since its introduction in the country, as well as innovations and advances. Traditionally, propagation is carried out through seeds, cuttings and by grafting on top of common acerola rootstocks, with no defined origin. The advances presented are focused on the use of new canopy and rootstock varieties, including the use of double grafting, minicutting and tissue culture, with studies still in progress, and use of new substrates such as coconut fiber.

Index terms: Malpighia spp.,acerola, seedling management, plant pathology.

\section{Avanços na propagação da aceroleira}

Corresponding author:

rogerio.ritzinger@embrapa.br

Received: September 21, 2016.

Accepted: May 23, 2017

Copyright: All the contents of this journal, except where otherwise noted, is licensed under a Creative Commons Attribution License.
Resumo - A aceroleira (Malpighia emarginata Sessé \& Moc. ex DC.) é uma frutífera que tem prosperado nas regiões tropicais brasileiras, especialmente no Nordeste, graças ao elevado teor de vitamina $\mathrm{C}$ nos frutos, dentre outras características que a tornam atrativa ao produtor, como precocidade de produção. Apesar de haver demanda crescente pelo produto, a produção de mudas certificadas de boas variedades comerciais ainda é um entrave para uma maior expansão da cultura. Esta revisão tem o objetivo de apresentar, de forma abrangente, informações técnicas sobre como a propagação tem sido feita desde a sua introdução no país, bem como inovações e avanços. Tradicionalmente, a propagação é realizada via sementes, estaquia e por garfagem em fenda cheia no topo sobre porta-enxertos de aceroleira comum, sem origem definida. Os avanços apresentados são focados no emprego de novas variedades copa e porta-enxerto, incluindo a utilização de dupla enxertia, miniestaquia e cultura de tecidos, com estudos ainda em andamento, e uso de novos substratos como a fibra de coco.

Termos para indexação: Malpighia spp., acerola, manejo de mudas, fitossanidade. 


\section{Introduction}

The acerola tree (Malpighia emarginata Sessé \& Moc. ex DC.) is a fruit native to the Caribbean, Central America and North of South America, which found in Brazil conditions favorable to its commercial cultivation. It has great economic and social importance due to its high content of vitamin C, as well as the early initiation of fruit production, short fruit development period (21 days) and high number of annual crops (ranging from three to four without irrigation and six to seven under irrigation) (GONZAGA NETO et al., 1995; SALLA et al., 2002). Brazil stands out as the largest producer, consumer and exporter of acerola in the world (CARVALHO, 2000). It is cultivated commercially in most Brazilian states (ALVES, 1996), due to the production of fruits rich in bioactive compounds such as vitamin C (2,000 to $3,000 \mathrm{mg} / 100 \mathrm{~g}$ pulp), carotenoids and anthocyanins (AGUIAR, LIMA et al. 2002; LIMA et al., 2003). However, it is in the brazilian Northeast that acerola is best adapted because of its soil and climate conditions (PAIVA et al., 1999).

The acerola tree has traditionally been propagated by sexual (seeds) and asexual (grafting and cutting) methods. Chronologically, the cultivation of the acerola tree in Brazil began with the importation of seeds from Puerto Rico, by the Federal Rural University of Pernambuco, in the 1950s, arousing general interest due to the high content of vitamin $\mathrm{C}$ in the fruits. However, a significant, though disorganized, growth of commercial plantations, mostly consisting of sexually propagated seedlings, only occurred in the late 1980s and early 1990s. The high genetic variability present in these plantations, with the consequent lack of uniformity and low productivity, motivated the selection of genotypes with good agronomic traits and fruit quality for use as commercial varieties. The first prominent varieties vegetatively propagated for the brazilian Northeast were 'Flor Branca', 'Okinawa' and 'Sertaneja' (RITZINGER and RITZINGER, 2011). Since then, huge advances have been made in the availability of new varieties, rich in bioactive compounds, more suitable for uses like fresh consumption, pulp, juice and ascorbic acid extraction, by Embrapa Cassava and Fruits (Cabocla, Rubra, Tropicana, Morena and Mulata), by Embrapa Tropical Agroindustry (Apodi, Cereja, Frutacor, Roxinha and Jaburu) and by the company Niagro / Nichirei of Brazil (Junco). The Olivier variety, selected by a producer in São Paulo, is the main variety under cultivation in that brazilian State. Other varieties are further described by Ritzinger et al. (2003b). In the brazilian Northeast, the above varieties are propagated almost exclusively by top wedge grafting, since this method has the advantages of high successful rates, confirmed by Cardoso et al. (2010), low cost and simple to implement. Besides, the rootstock when originated from seed forms a pivotal root system which is welcome in a region very subject to water deficit. In a situation of subtropical climate and regular precipitations, the Olivier variety develops well in São Paulo, being locally propagated by means of rooted cuttings.

The choice of a rootstock represents another major breakthrough and a comparative advantage of grafting over rooted cuttings in this fruit crop. The acerola tree is vulnerable to nematode infestation, so efforts to select resistant / tolerant genotypes have been carried out (FERRAZ et al., 1989; PIPOLO et al., 1997; GOMES et al., 2000), still with no conclusive results. Current research at Embrapa Cassava and Fruits that may lead to innovations in the propagation of the acerola rootstock include studies of rootstock diversification with the selection and evaluation of genotypes of common acerola (M. emarginata), ornamental acerola (M. coccigera) and M. glabra for this purpose as well as the use of double grafting. Preliminary observations reveal that certain rootstocks may induce earlier production of the acerola tree, provide a reduction in the canopy volume and present tolerance to nematodes. In this regard, it has been observed that the common acerola tree is naturally tolerant to nematodes, since even infested plants continue to produce and compensate for the attack by the emission of new roots provided that it receives the appropriate cultural treatments to remain productive.

\section{Propagation by seeds}

The seed propagation had an important initial importance in the formation of the first commercial orchards of acerola in Brazil, and was described appropriately by Ritzinger and Ritzinger (2011) as follows: "The seeds must be taken from ripe fruits, washed in a wire sieve to remove the skin and pulp (Figure 1A), and dried in the shade; considering that the presence of viable seeds in the cores is low, between 20 and 50\%, it is recommended to increase, in the same proportion, the quantity of seeds to be sown (Figure 1B); sowing can be done in rows or randomly spreading the seeds onto the well-drained porous substrate, usually consisting of washed sand and vermiculite, in the proportion of $1: 1$ by volume, arranged in wooden, plastic or styrofoam boxes; then the seeds must be covered with a layer of $1.0 \mathrm{~cm}$ of substrate and placed in a shaded place; the emergence of seedlings begins two to three weeks after sowing, and they are transplanted into black polyethylene bags containing the growth substrate when they present two to three pairs of leaves (Figure 1C); after transplanting, the developing plants (Figure 1D) should be conducted in nurseries, with natural luminosity around 50\%; plants with 25 to $40 \mathrm{~cm}$ height are suitable for planting in the field, after being acclimatized to direct sunlight or for use as rootstocks. " 
Currently, the use of seed propagation is recommended only for the formation of seedlings in nurseries to be used as rootstocks and, in breeding programs, for the creation of open-pollinated progenies in order to exploit the great existing variability for the selection of genotypes with good agronomic characteristics for use as commercial varieties; on the other hand, this method of propagation is contraindicated to the producer due to the great disparity between plants, which results in low productivity and poor fruit quality, as well as low seed germination (RITZINGER and RITZINGER, 2011).

\section{Vegetative propagation}

This type of propagation is defined as a form of asexual reproduction in plants in which new individuals (clones) are formed from vegetative parts, the new plant being genetically identical to the parent plant, with the exception of mutations that may occasionally occur (TOOGOOD, 1999). Vegetative propagation has the advantage of clone perpetuation and inducement of earlier production compared to plants of sexual origin (HARTMANN et al., 1990). In the case of acerola, the most commonly used methods are the top wedge grafting and rooted cuttings.

\section{Grafting}

Grafting involves the combination of parts of two plants with different genetic characteristics in a single individual aiming to associate benefits of the rootstock, which represents the already formed root system, and a branch portion of a selected variety, which will come to form the canopy (TOOGOOD, 1999). In the rootstock variety, the traits sought are the tolerance to water deficit, tolerance and / or resistance to nematodes, especially of the genus Meloidogyne, and the ease of propagation, mainly. In the canopy variety, characters related to production, fruit quality and growth habit, as well as resistance to diseases and pests are sought (RITZINGER et al., 2003b).

Acerola grafting, as described by Ritzinger and Ritzinger (2004), "should be performed when the rootstock reaches the approximate diameter of a pencil $(7 \mathrm{~mm})$ at a height of 15 to $20 \mathrm{~cm}$ from the soil surface. The most commonly used method is the top wedge grafting (PEDROSA et al., 1994). The scion should be taken from semi-woody growth of the year, with three to four buds, free of pests and diseases and collected from stock plants of the selected varieties. For grafting to succeed, it is important that the scion has the same diameter as the rootstock at the grafting site. In addition, it is recommended to be carried out during the warmer months of the year, when the plants are in full vegetative development, as it favors healing. The process begins with the cutting of the rootstock at the height of 15 to $20 \mathrm{~cm}$, and the cut of the base of the scion should be wedge-shaped (Figure 2A). Then, a vertical incision is made in the center of the rootstock (Figure 2B) and the scion is adjusted in this incision, taking care to make a perfect alignment of both so that they match on at least one side, for tissue healing to occur (Figure 2C). Subsequently, the graft is wrapped with a polyethylene film (Figure 2D) and its protection with a plastic bag to avoid dryness, maintaining it until new shoots are sprouted (Figure 2E). Under suitable conditions, a high percentage of success is expected, over $90 \%$, and the plant should be ready for planting in the field about 90 days after grafting, with mature primary branches and mature leaves (Figure $2 \mathrm{~F})$. The polyethylene film used for wrapping the graft must be removed after planting, otherwise it will cause choking at the grafting site."

Embrapa Cassava and Fruits has used seeds of the genotype CMF102 (variety BRS Robusta) as rootstock, with good results, for several years (RITZINGER et al., 2003b). In addition, the species M. glabra and $M$. coccigera have been tested as rootstocks for acerola. Woody cuttings of the first species were found to be easily rooted, and grafting was found to be compatible with scions of $M$. emarginata. It has been observed that M. coccigera induces less vigor to the plants, possibly due to the smaller development of its root system and, under cultivation in pots, this rootstock induced earliness of production and greater number of fruits in the variety of acerola 'Rubra' compared to the same variety grafted onto rootstocks of CMF102 plants (M. emarginata).

\section{Cuttings and minicuttings}

In the method of propagation by cuttings, new plants are produced by the rooting of pieces of stems, which can be herbaceous, semi-woody, woody or minicuttings. In this method a regenerative process of branches and adventitious roots occurs from the nodal regions of the cuttings. The success of the process is dependent on the genotype, stem quality, leaf presence, aseptic conditions for the control of soil fungi and nematodes, temperature control, humidity and light inside the greenhouses, type of substrate and use of growth regulators, tending to have higher costs than grafting methods (EZEKIEL, 2010).

Ritzinger and Ritzinger (2011) suggest that cuttings should be turgid and collected during the period of vegetative growth, preferably in the morning. They should contain a pair of apical leaves and be planted immediately, in boxes or trays containing porous substrate, usually sterilized washed sand and vermiculite in the volume ratio of $1: 1$. The base of the cuttings can be disinfected by immersion for 20 minutes in $0.5 \%$ solution of sodium hypochlorite (OLKOWSKI et al., 2013), and later treated with growth regulators such as indolebutyric acid (IBA) to accelerate the emission of roots. Good results were 
obtained in concentrations of IBA ranging from 400 to $2,800 \mathrm{mg} \mathrm{L}$, in immersion for five seconds (ALVES et al., 1991; DUARTE et al., 2000, GONTIJO et al., 2003, VERNIER and CARDOSO, 2013 ). However, the absence of satisfactory responses with the use of IBA was observed in some studies (BORDIN et al, 2003). It is important that the cuttings stay in an environment of reduced luminosity (screenhouse with 50\% shade), cool temperatures and high relative humidity, which can be obtained by means of an intermittent mist irrigation system or completely covering boxes or trays with transparent plastics bags. The rooting of the cuttings usually occurs between 40 to 60 days, and rooting efficiency can vary according to the genotype, type of substrate used and environmental conditions in the nursery (NAKASONE and PAULL, 1988; VERNIER and CARDOSO, 2013). After rooting, the cuttings are transplanted into tubes or black polyethylene bags containing the growth substrate. The rooting of woody cuttings of $M$. coccigera is shown in Figure 3.

The method of propagation by minicuttings has the advantage of rapid obtaining of propagules (minicuttings), in great amount, in a short time (RITZINGER and RITZINGER, 2003). Ritzinger and Grazziotti (2005) proposed a low-cost method of propagation of acerola by minicuttings with the use of plastic trays. In this method, the plants are produced from 2.0 to $4.0 \mathrm{~cm}$ long apical herbaceous cuttings taken from new shoots, with one to two pairs of leaves, collected from the stock plants of the selected varieties. To encourage the emergence of shoots, the authors recommend pruning the stock plants eliminating the upper third of the branches. Factors such as time of year, irrigation and fertilization also influence the development of shoots. For the production of healthy minicuttings it is important to monitor and, if necessary, control pests, especially aphids and mites, which may hamper the growth of shoots.

Considering that it is a tender and delicate material that easily deteriorates, it is important for the success of the method that minicuttings remain turgid, so Ritzinger and Grazziotti (2005) recommend that they should be collected in the morning during the vegetative growth period. The minicuttings are cut with scissors, also used to cut a third of the more developed leaf limbs, aiming to reduce the transpiration rate. Even so, immediately after the cut, they recommend placing the minicuttings in a container with water until the moment of planting, preventing its dehydration. After collection, minicuttings should be promptly planted in boxes or plastic trays 9.0 $\mathrm{cm}$ deep and perforated bottom. The boxes should be filled halfway with porous substrate, preferably washed sand and vermiculite, in the proportion of $1: 1$ by volume, previously moistened. The base of the cuttings can be treated with growth regulators, such as indolebutyric acid (IBA), to accelerate root emission as mentioned above. It is important to sterilize the substrate to avoid the presence of microorganisms that can cause the rotting of the minicuttings. The trays should be kept in a low-lit environment (lath or screenhouse with 50\% shading), cool and saturated with moisture, which can be obtained by installing an intermittent misting irrigation system, or completely covering the boxes or trays with transparent plastic bags, which are supported by wire archs. In this case, minicuttings should be sprayed with water at intervals of two to three days (Figure 4). Plants produced from minicuttings show morphological differences in the growth of aerial and root parts compared to acerola plants produced by grafting, depicted in Figures 5 and 6. Plants developed from minicuttings tend to form a single stem, which requires pruning to stimulate the emergence of lateral shoots that will give rise to the main branches, and have a root system of adventitious origin, more superficial and, therefore, the plants are more subject to infestation of nematodes, water stresses and to tilt or fall down in places of strong winds (RITZINGER and RITZINGER, 2003).

\section{Tissue culture}

The propagation of the acerola tree by tissue culture is not in practice yet, with an established and defined protocol, so that further research is needed. Attempts to establish in vitro plants at Embrapa Cassava and Fruits had problems with endogenous tissue contamination. The same was observed by Braga et al. (1997), who concluded that herbaceous explants between the apex and the fourth nodal segment contaminate less and present better yields of shoot number and shoot length. Another relevant factor is the genotype, also observed by Melo et al. (1999), which has great importance in determining the capacity of sprouting and in vitro development. In addition, both authors reported the low efficiency of the MS medium for acerola, and Melo et al. (1999) obtained superior results with WPM (McCown Woody Plant medium) and DKW (Driver Kuniyuki Walnut medium).

\section{Field clonal garden}

The installation of a bank of stock plants or a clonal garden, which is an orchard consisting of one or more groups of cloned plants (stock), certified and supervised by the competent government agencies, is essential for the supply of healthy, good quality scions and cuttings in quantity and genetically identical for the vegetative propagation of a plant species (CARVALHO and SILVA, 2012). In the case of acerola, it is advisable that the clonal garden be located near the nursery, but distant from the commercial plantation, being constituted of plants of the varieties to be propagated, in the spacing of $1.0 \mathrm{~m}$ between plants in the rows and $2.0 \mathrm{~m}$ between rows. The cultural practices consist of fertilization, control of weeds, pests and diseases and pruning to maintain a constant 
production of vigorous stems in the juvenile stage for use as propagules in the nursery.

\section{Substrates}

The preparation of a suitable substrate, which contains the nutrients necessary for the development of the plants and which is free of plant parasitic nematodes, pathogenic fungi and weeds, is essential for the production of healthy acerola seedlings. Damping off, caused by Rhizoctonia sp., and the presence of nematodes of the genus Meloidogyne causing root galls are the main phytosanitary problems in the production of acerola seedlings, which can be caused by the use of contaminated substrates or poor quality irrigation water. In addition, nutrient poor and clayish substrates with low aeration cause slow growth of seedlings (RITZINGER et al., 2003a).

\section{Substrates for rooting and seed germination}

As a substratum for rooting cuttings and for seed germination it is recommended to use sand of medium texture, washed and sterilized, mixed with vermiculite in the ratio of $1: 1$ by volume (NAKASONE and PAULL, 1988). If the sand originates from places near the sea, special attention should be given to washing to remove excess salt. Other components of substrates, such as carbonized rice husk, burned pine bark and coconut fiber, among others mentioned by Mattson and Fulcher (2015), have not yet been tested as a substrate for the production of acerola seedlings. In eucalyptus seedlings, substrates based on carbonized rice husks, combined or not with coconut fiber, provided low growth of the seedlings (KRATZ and WENDLING, 2013), and better results were obtained with a substrate made up of carbonized rice husk and vermiculite followed by commercial substrates based on partially decomposed pinus bark and vermiculite. However, these authors did not rule out the use of coconut fiber because of its good attributes of water retention and porosity that classify it as an important material to compose substrates for seedlings, and suggested adjustments in the water management in the nursery that should be specific to each type of substrate composition. This may help explain the positive results obtained by Simões et al. (2012) in the evaluation of substrates for the production of eucalyptus seedlings in tubes, in which the 1:1 mixture of carbonized rice husk and coconut fiber was highlighted, as well as the 1:1 mixture of vermiculite and coconut fiber. In their research with the objective of evaluating substrates for the production of mate herb seedlings, Kratz et al. (2015) reported that those containing balanced proportions of coconut fiber and carbonized rice husk favored the root development of the seedlings. However, Castilhos (2011) states that to be efficient, the use of the coconut fiber substrate in planting seedlings must undergo a composting process. For this, Castilhos (2011) suggests the mixture of three parts of coconut fiber with a part of poultry manure and $2 \mathrm{~kg} / \mathrm{m} 3$ of phosphate, leaving it composting for 60 days and stir the compound every 15 days. Afterwards, it should be stored in a clean, dry and covered place.

Special care must be given to the containers (plastic trays and wooden boxes), where the substrate will be placed, which must be washed with soap and water and disinfested with $1.0 \%$ sodium hypochlorite (bleach, which has 2.0 to $2.5 \%$ active ingredient, diluted in distilled water 1: 1 ratio by volume).

\section{Substrates for growing}

For the preparation of a good quality substrate for the growth of the acerola seedlings there are two options, as described by Ritzinger et al. (2003a):

A) to formulate the substrate from materials free of plant pathogenic microorganisms and weeds. In this case, the following mixture is recommended, adapted from Sempionato et al. (1997) - composite product based on burned pine bark (180 L), vermiculite $(20 \mathrm{~L})$, castor bean cake $(3 \mathrm{~L})$, dolomitic limestone $(0.6 \mathrm{~kg})$ and NPK formula $10-10-10(0.5 \mathrm{~kg})$. A new substrate alternative that exists in the brazilian market nowadays is coconut fiber, which can be used in the formation of seedlings. This material is characterized by being biodegradable, in addition, it has high porosity, high aeration capacity, slow decomposition and good moisture retention capacity. However, its use alone is not recommended. Simões et al. (2012) recommended the balanced blend of coconut fiber with carbonized rice husk or vermiculite in equal parts. Taveira (2016) states that coconut fiber needs to be supplemented with extra sources of nutrients by fertigation or use of slow release fertilizers such as osmocote;

B) constituting substrates by mixing organic soil, sand, tanned manure of animals (catttle, goat and poultry), among other materials, and subjecting them to disinfestation. There is also the alternative of using deeper layer soils (red soil), common in the production of seedlings in Brazil because it is a cheaper alternative and where the possibility of occurrence of plant parasitic nematodes and other pathogenic microorganisms is smaller due to the absence of organic matter. It should be mixed with washed sand at the ratio of 1: 1 by volume, although this procedure does not diminish the importance of disinfestation of the substrate.

\section{Disinfestation of the substrates}

Disinfestation is an important operation that aims to eliminate the plant pathogenic microorganisms and weed propagation structures present in the substrate, which can cause death of the seedlings and serve as a source of inoculum for dissemination in the transplantation to the definitive site. 
Among the alternatives currently available for the disinfestation of rooting, germination and growing substrates, the use of solarization is recommended, since it is a simple and inexpensive method based on solar heating (BETTIOL and GHINI, 2003). In this process, the substrate, laid in layers of 10 to $20 \mathrm{~cm}$ and moistened near the field capacity, is covered with a transparent plastic film and exposed directly to the sunlight.

The transparent plastic should be in direct contact with the substrate and have its edges buried, avoiding the loss of heat. The efficiency of the process, which should last four to eight weeks, depends on the high temperatures reached internally, which are obtained in the warmer months and with higher solar incidence. Temperatures of $60{ }^{\circ} \mathrm{C}$ eliminate most plant pathogenic soil microorganisms, including nematodes, while allowing the survival of several beneficial microorganisms that are thermotolerant, thus making it difficult the reinfestation by soil pathogens. Humidity favors the germination of the propagative structures of plant pathogens and weeds making them sensitive to the action of heat, as well as improves the conduction of heat to the deeper layers of the substrate that is being treated. Stirring the substrate and prolonged stay of the plastic increases the efficiency of disinfestation.

The disinfestation can also be effective through a solar collector, developed by Embrapa EnvironmentCNPMA(GHINI, 1997), which presents as advantages the immediate use of the substrate and the shortest treatment time, from one to two days, reaching temperatures from 70 to $80^{\circ} \mathrm{C}$. The solar collector consists of a wooden box with metal tubes, in which the substrate to be treated is placed, which in this case should not be very humid, and which is covered with transparent plastic. Its installation should occur with exposure to the north face and the angle of inclination similar to the local latitude plus $10^{\circ}$. The soil is placed in the tubes through the upper opening and, by force of gravity, is withdrawn through the lower opening. The disinfested substrate can be stored for use in times when the insolation is lower.

Another feasible alternative is the use of a steam soil sterilizer. The existing equipment at Embrapa Cassava and Fruits allows the sterilization of $4 \mathrm{~m} 3$ of soil at a time, which is submitted to a constant temperature of $120^{\circ} \mathrm{C}$ for three hours.

\section{Pests and diseases in the nursery}

At Embrapa Cassava and Fruits, in Cruz das Almas, BA, about 2,000 acerola plants are produced annually in a screenhouse under $50 \%$ shade. This condition favors their development, and is also suitable for the systematic occurrence of various pests and diseases, which can damage the plants.

Among the pests that affect acerola plants in the screenhouse, described by Ritzinger et al. (2008a), stand out the green citrus aphid (Aphis spiraecola) and black citrus aphid (Toxoptera citricidus), phytophagous mites belonging to the families Tetranychidae (red mite) and Tarsonemidae (white mite), the lace bug (Gargaphia torresi) and the gall nematode (Meloidogyne spp.). There is no record of varietal materials resistant to pest infestations in acerola, which can be controlled by the use of useful insects (predators and parasitoids), neem oil based products and, in the case of nematodes, with preventive measures using exempt substrates and the aseptic cleaning of the nurseries.

Several diseases attack the acerola plant, whose severity depends on the region and climatic conditions. According to Ritzinger et al. (2008), the most common diseases in acerola plants in the screenhouse at Embrapa Cassava and Fruits are anthracnose (Colletotrichum gloeosporioides) and cercospora leaf spot (Cercospora sp.), which can cause intense defoliation and for which varietal resistance among progenies is observed. The incidence of damping-off (Rhizoctonia sp.) causes seedling death and needs to be monitored and controlled with the use of free, sterilized substrates and good quality irrigation water. Ritzinger et al. (2015) mention that some management practices in the screenhouse may disadvantage the development of diseases, such as the use of resistant varieties, maintenance of adequate plant nutrition, as well as pruning or adequate spacing to reduce excess moisture. 

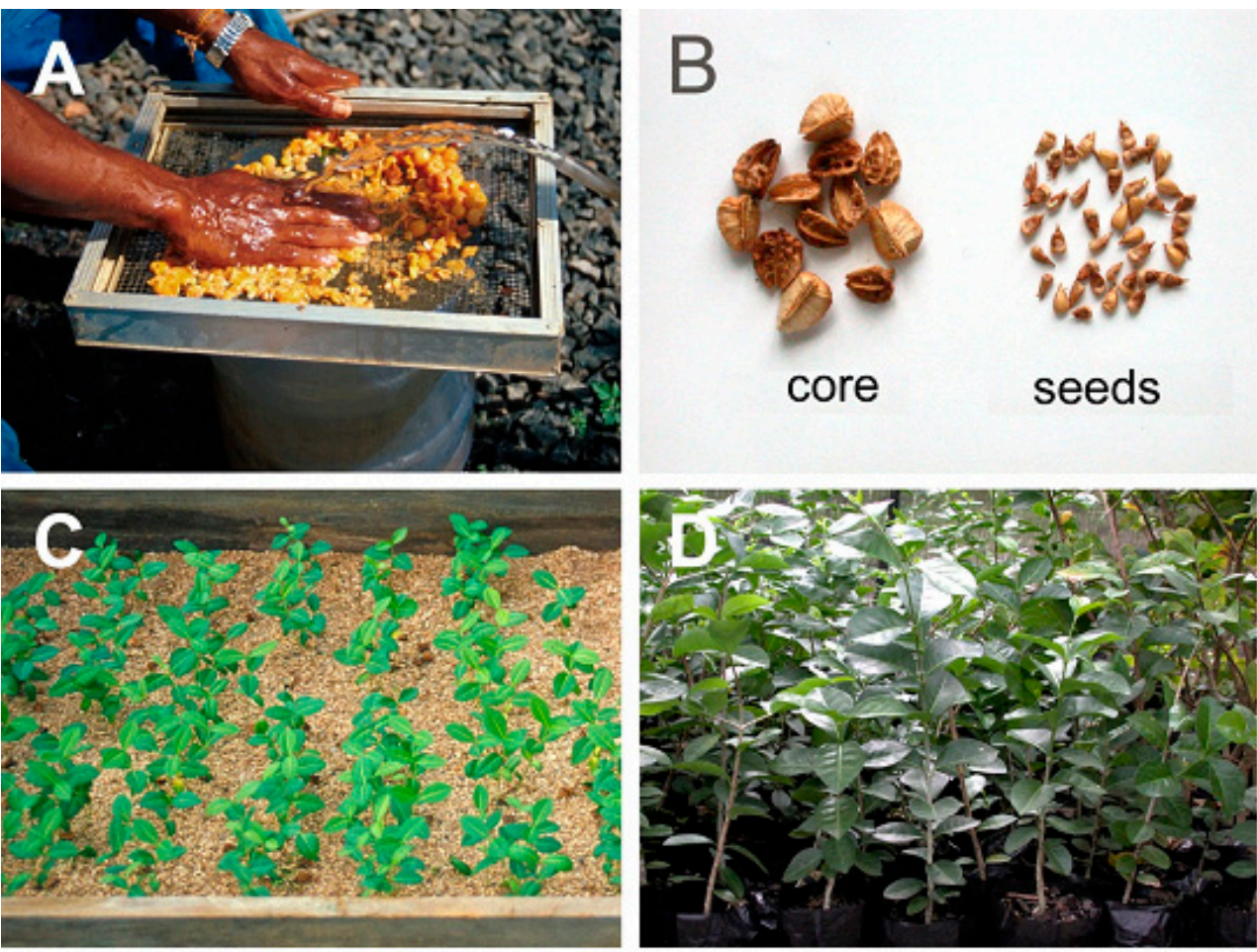

Figure 1 - Production of acerola seedlings (Malpighia emarginata). (A) steps involving the process of fruit pulping, washing, sifting and separation of cores; (B) dry cores containing the seeds and seeds removed from the interior of the cores (C) seedlings emerged in sand bed and (D) plants under development in black polyethylene bags (Photos: Rogério Ritzinger).
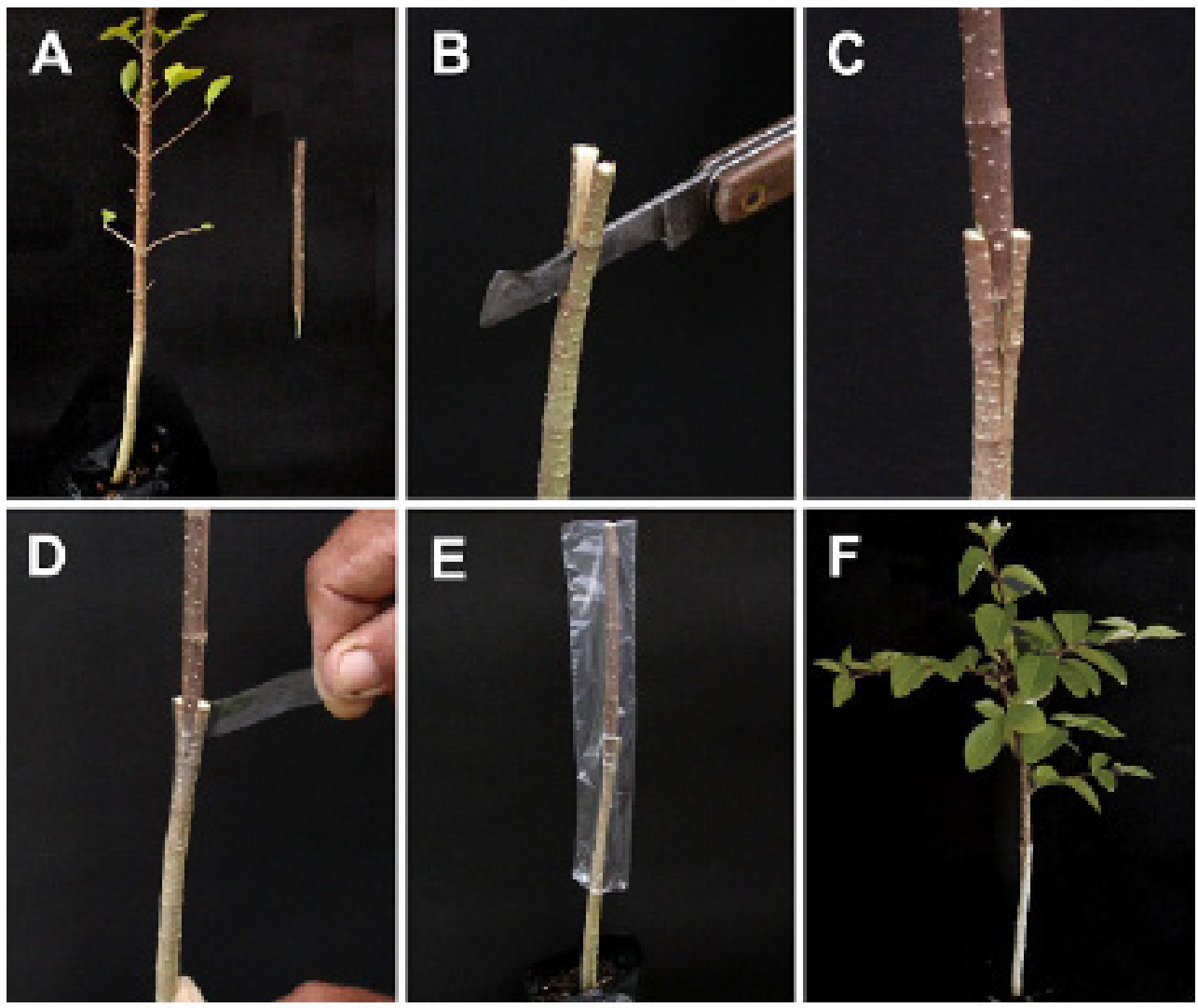

Figure 2- Stages of the process of top wedge grafting in the acerola plant (Malpighia emarginata). (A) selection, cutting and preparation of the scion and rootstock and wedge-shaped cut at the base of the scion so that it can be fixed in the rootstock; (B) open slit in the rootstock for grafting; (C) the scion with the wedge-shaped cut at the base is introduced into the open slit; (D) wrapping with plastic tape for union between scion and rootstock; (E) the scion is covered with a transparent plastic bag to form a humid chamber and avoid dryness and (F) grafted plant ready for planting (Photos: Rogério Ritzinger). 

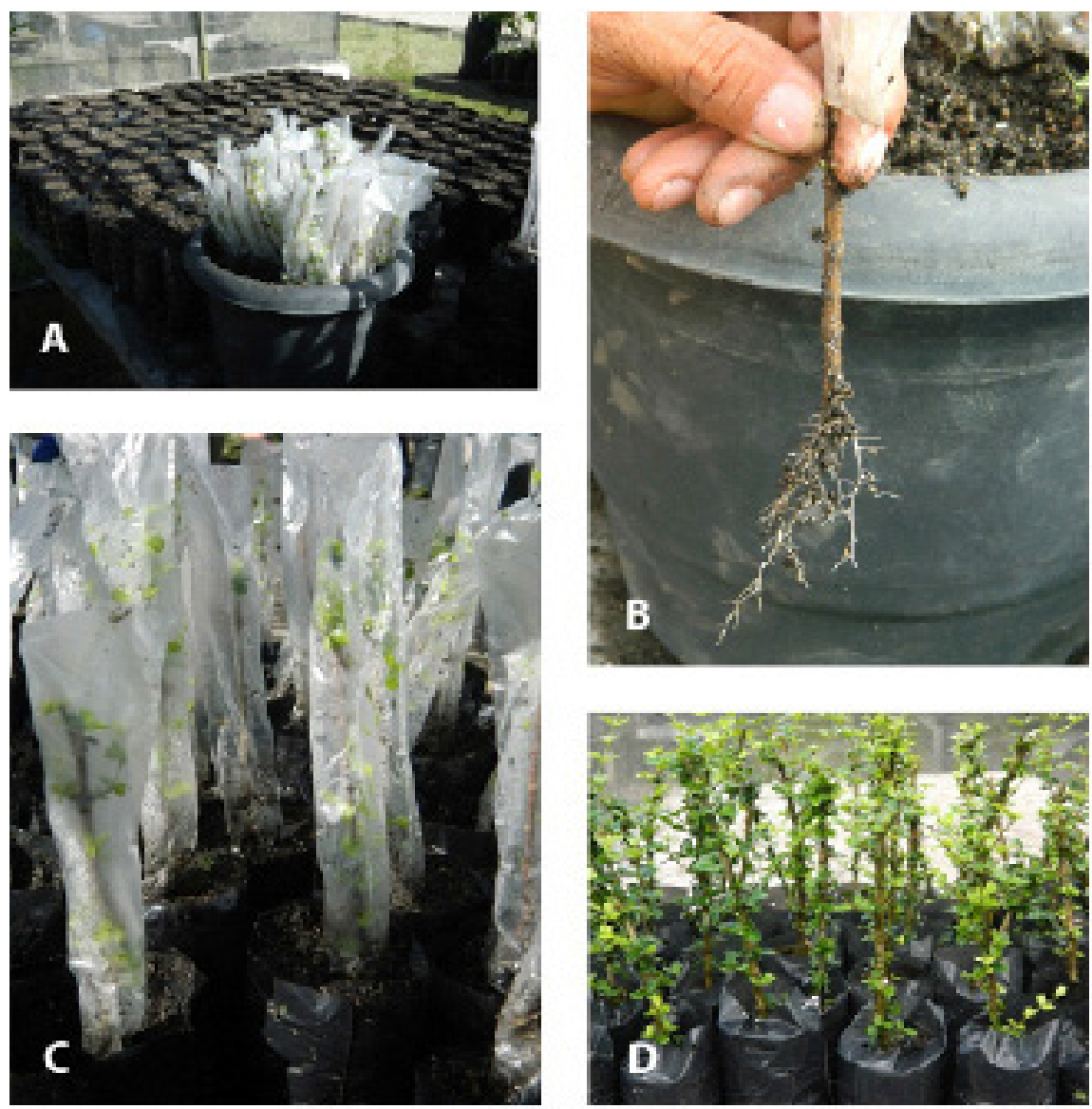

Figure 3 -Stages of the rooting process of woody cuttings of Malpighia coccigera for use as rootstock. (A) Woody cuttings in container with rooting substrate individually protected with transparent plastic bags; (B) cuttings with roots after 60 days; (C) rooted cuttings transplanted to black polyethylene bags; (D) successful rooted plants in full development awaiting grafting (Photos: Rogério Ritzinger).
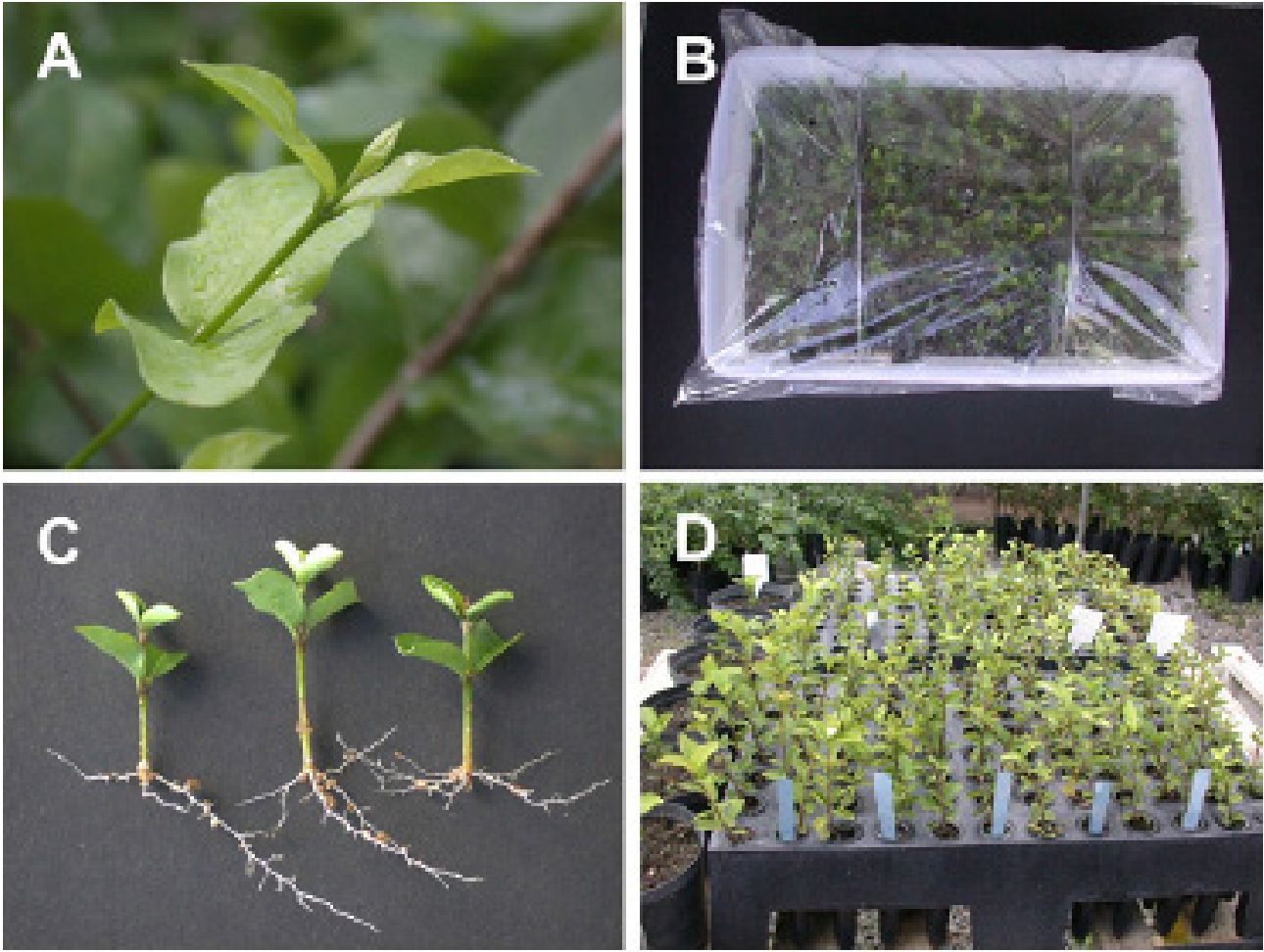

Figure 4 -Stages of the method of propagation of acerola plants (Malpighia emarginata) by minicuttings. (A) new sprouting, ideal for use as minicutting; (B) tray with minicuttings covered with clear plastic; (C) rooted minicuttings; (D) plants developed from minicuttings transplanted to tubes (Photos: Rogério Ritzinger). 


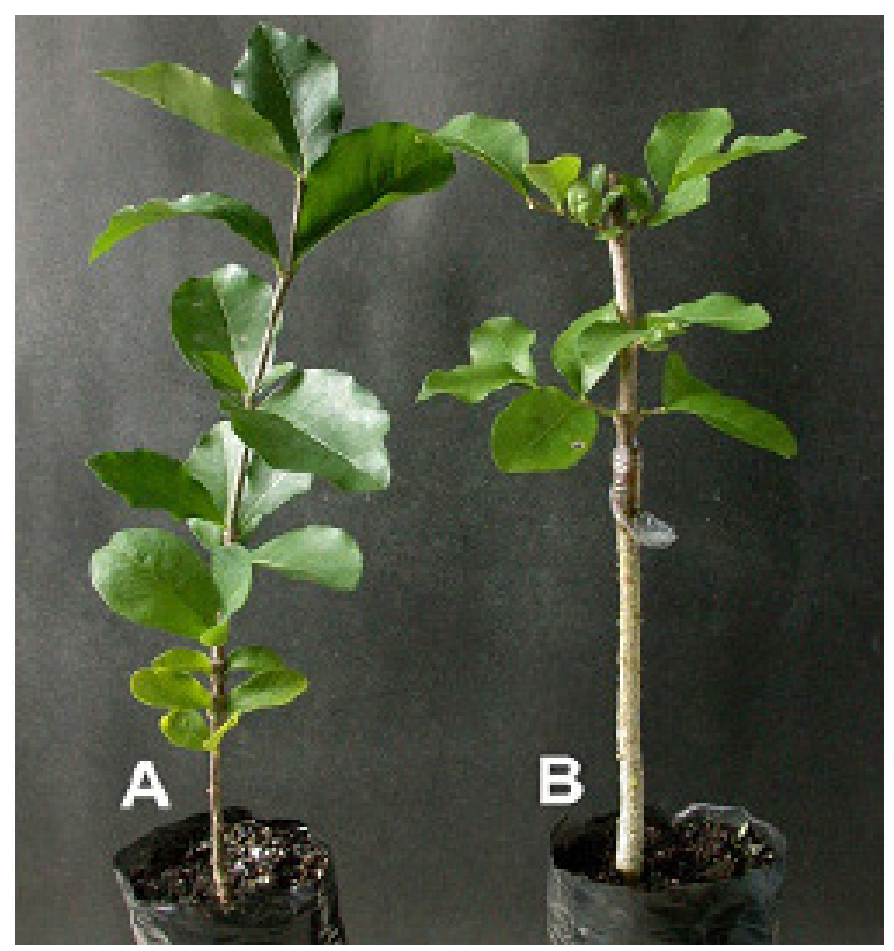

Figure 5- Aerial part of acerola plants (Malpighia emarginata). (A) from rooted minicutting; (B) from top wedge grafted plant (Photo: Rogério Ritzinger).

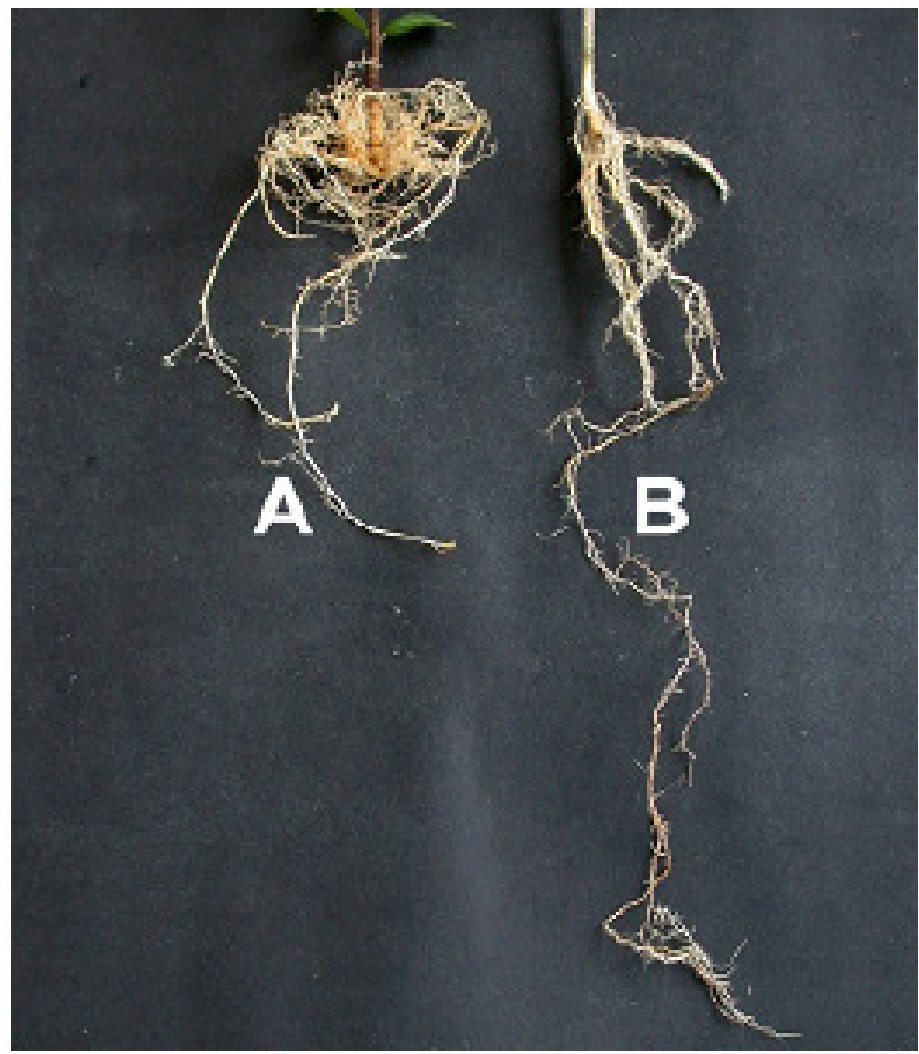

Figure 6- Root system of acerola plants (Malpighia emarginata). (A) from rooted minicutting; (B) from top wedge grafted plant. (Photo: Rogério Ritzinger). 


\section{References}

ALVES, R. E. Características das frutas para exportação. In: GORGATTI NETTO, A.; ARDITO, E. F. G.; GARCIA, E. E. (Ed.). Acerola para exportação: procedimentos de colheita e pós-colheita. Brasília, DF: EMBRAPA-SPI, 1996. p.9-12. (Série Publicações técnicas FRUPEX, 21).

ALVES, R. E.; SILVA, A. Q. da; SILVA, H.; MUSSER, R. dos S. Contribuição ao estudo da cultura da acerola. I. Efeitos do IBA e da sacarose no enraizamento de estacas. Revista Brasileira de Fruticultura, Jaboticabal, v.13, n.2, p.19-26, 1991.

BETTIOL, W.; GHINI, R. Controle físico de doenças de plantas invasoras. In: CAMPANHOLA, C.; BETTIOL, W. (Ed.). Métodos alternativos de controle fitossanitário. Jaguariuna: Embrapa Meio Ambiente, 2003. p.165-189.

BORDIN, I.; ROBERTO, S. R.; NEVES, C. S. V. J.; STENZEL, N. M. C.; FURLANETO, T. L. R. Enraizamento de estacas de acerola sob concentrações de ácido indol-butírico. Semina: Ciências Agrárias, Londrina, v.24, n.2, p.261-264, 2003.

BRAGA, M.F.; CALDAS, L.S.; HABE, M.H. Estabelecimento de acerola (Malpighia glabra L.) in vitro: efeito do clone e do explante. Revista Brasileira de Fruticultura, Jaboticabal, v.19, n.3, p.335-346, 1997.

CARDOSO, E.de A.; SILVA, R.M.da; AGUIAR, A.V.M.de; ARAGÃO, R.G. Métodos de enxertia na produção de mudas de acerola (Malpighia emarginata D.C.). ACSA-Agropecuária Científica no Semi-Árido, Campina Grande, v.6, n.4, p.28-32, 2010.

CARVALHO, J.M.F.C.; SILVA, M.M. de A. Plantas matrizes na propagação vegetativa. Campina Grande: Embrapa Algodão, 2012. 36 p. (Documentos, 242).

CARVALHO, R.A. Análise econômica da produção de acerola no município de Tomé-Açú, Pará. Belém: Embrapa Amazônia Oriental, 2000. 21p. (Documentos, 49).

CASTILHOS, L.F.F. de. Aproveitamento da fibra de coco. Curitiba: Instituto de Tecnologia do Paraná, 2011. 24p. (Dossiê Técnico).

CASTRO, J.M. da C.; RIBEIRO, J.M.R.; RIBEIRO JÚNIOR, P.M.; ALMEIDA, E.J. de; SOUSA, A.D. de; OLIVEIRA, P.G. de. Reprodução do nematoide-dasgalhas da goiabeira em acessos de Psidium. Comunicata Scientiae, Bom Jesus, v.8, n.1, p.149-154, 2017.
DUARTE, R.O.; MOREIRA, M.A.B.; BENEZAR, R.M.C.; COSTA, M.I. da S.; FREITAS, F.N. de; ALVES JUNIOR, H. de O.; AMORIM, J.E.L.; DIAS, M.R.N. Efeito do ácido indolbutírico (AIB) em duas épocas, no enraizamento de estacas semilenhosas de acerola (Malpighia glabra L.) em estufins. In: CONGRESSO BRASILEIRO DE FRUTICULTURA, 16., 2000, Fortaleza. Resumos... Fortaleza: SBF, 2000. p.49.

EZEKIEL, A. Viable options and factors in consideration for low cost vegetative propagation of tropical trees. International Journal of Botany, Dubai, v.6, n.2, p.6980, 2010.

FERRAZ, L.C.C.B.; MONTEIRO, A.R.; INOMOTO, M.M. Hospedabilidade da acerola em relação a sete espécies de fitonematóides. Nematologia Brasileira, Piracicaba, v.23, p.39-49, 1989.

GHINI, R. Desinfestação do solo com o uso de energia solar: solarização e coletor solar. Jaguariúna: Embrapa CNPMA, 1997. 29p. (Circular, 1)

GOMES, J.E.; SANTOS, J.M. dos; PERECIN, D.; MARTINS, A.B.G. Resistência de clones de acerola (Malpighia emarginata D.C.) à Meloidogyne javanica em condições de casa de vegetação. Nematologia Brasileira, Brasília, DF, v.24, n.1, p.65-71, 2000.

GONTIJO, T.C.A.; RAMOS, J.D.; MENDONÇA, V.; PIO, R.; ARAÚJO NETO, S.E. de; CORRÊA, F.L. de O. Enraizamento de diferentes tipos de estacas de aceroleira utilizando ácido indolbutírico. Revista Brasileira de Fruticultura, Jaboticabal, v.25, n.2, p.290-292, 2003.

GONZAGA NETO, L.; SOARES, M.S.; CHOUDHURY, M.M.; LEAL, I.M. A cultura da acerola. Brasília: Embrapa - SPI, 1995. 101p.

HARTMANN, H. T.; KESTER, D. E.; DAVIES JR., F. T. Plant propagation: principles and practices. Englewood Cliffs: Regents/Prentice Hall, 1990. 647p.

KRATZ, D.; PIRES, P.P.; STUEPP, C.A.; WENDLING, I. Produção de mudas de erva-mate por miniestaquia em substratos renováveis. Floresta, Curitiba, v.45, n.3, p.609-616, 2015.

KRATZ, D.; WENDLING, I. Produção de mudas de Eucalyptus dunnii em substratos renováveis. Floresta, Curitiba, v.43, n.1, p.125-136, 2013.

LIMA, V.L.A.; MÉLO, E.A.; MACIEL, M.I.S.; LIMA, D.E.da S. Avaliação do teor de antocianinas em polpa de acerola congelada proveniente de frutos de 12 diferentes aceroleiras (Malpighia emarginata D. C.). Ciência e Tecnologia de Alimentos, Campinas, v.23, n.1, p.101-103, 2003. 
MATTSON, N.S.; FULCHER, A. Substrates and containers for seed and cutting propagation and transplanting. In: BEYL, C.A.; TRIGIANO, R.N. (Ed.). Plant propagation concepts and laboratory exercises. Boca Raton: CRC, 2015. p.127-144.

MELO, N.F.; OKASAKI, W.Y; LEITE, C.B.; FÁRI, M. Estabelecimento do cultivo in vitro da aceroleira (Malpighia emarginata DC.). Ciência e Agrotecnologia, Lavras, v.23, n.1, p.102-107, 1999.

NAKASONE, H.Y.; PAULL, R. E. Other american tropical fruit: acerola. In: NAKASONE, H.Y.; PAULL, R.E. Tropical fruits. Oxon: CABI, 1998. p. 377-388. (2) corrigir na p.7 linha 14 e p. 10 linha 5 (NAKASONE e PAULL, 1988 para (NAKASONE e PAULL, 1998).

OLKOWSKI, W.; DAAR, S.; OLKOWSKI, H. The gardener's guide to common-sense pest control. Newton: The Taunton, 2013.383p.

PAIVA, J. R.; ALVES, R. E.; BARROS, L. M. Melhoramento genético da aceroleira (Malpighia emarginata D.C.) na Embrapa Agroindústria Tropical. In: QUEIROZ, M.A. de; GOEDERT, C.O.; RAMOS, S.R.R. Recursos genéticos e melhoramento de plantas para o nordeste brasileiro. Petrolina: Embrapa Semi-Árido/ Brasília: Embrapa Recursos Genéticos e Biotecnologia, 1999.

PEDROSA, A.C.; FREITAS, E.V.de; LEDERMAN, I.E.; BEZERRA, J.E.F. Influência do processo de enxertia por garagem na propagação da aceroleira em Pernambuco. In: CONGRESSO BRASILEIRO DE FRUTICULTURA, 13., 1994, Salvador. Resumos... Salvador: SBF, 1994. v.1, p.78-79.

PIPOLO, V.C.; ZANATTA, S.; GRANGE, L.; POPPER, I.O.; GONZALEZ, M.G.N.; PRETE, C.E.; KZRYZANOWSKI, A. Relação entre a concentração de ácido ascórbico e a resistência de acerola (Malpighia glabra L.) ao nematoide das galhas. Nematologia Brasileira, Brasília, DF, v.21, n.1, p.20, 1997.

RITZINGER, C. H. S. P.; FANCELLI, M.; RITZINGER, R.; COELHO FILHO, M. A. As interações ecológicas e a sua biodiversidade funcional em sistemas de fruteiras em transição agroecológica. In: SANTILLI, J.; BUSTAMANTE, P.G.; BARBIERI, R.L. (Ed.). Agrobiodiversidade. Brasília, DF: Embrapa, 2015. p.169-191.

RITZINGER, R.; GRAZZIOTTI, P. H. Produção de mudas de acerola por miniestaquia. Cruz das Almas: Embrapa-CNPMF, 2005. 2p. (Acerola em Foco, 10).
RITZINGER, R.; NORONHA, A.C.S.; FARIAS, A.R.N.; RITZINGER, C.H.S.P.R.; NASCIMENTO, A.S. Pragas em viveiro de mudas de aceroleira. Cruz das Almas: Embrapa-CNPMF, 2008a. 2p. (Acerola em Foco, 12).

RITZINGER, R.; RITZINGER, C.H.S.P.R. Produção de mudas de acerola por enxertia. Cruz das Almas: Embrapa - CNPMF, 2004. 2p. (Acerola em Foco, 08)

RITZINGER, R.; RITZINGER, C.H.S.P.R. Propagação da aceroleira: enxertia $x$ estaquia. Cruz das Almas: Embrapa - CNPMF, 2003. 2p. (Acerola em Foco, 04)

RITZINGER, R.; RITZINGER, C.H.S.P.R.; CORDEIRO, Z.J.M. Doenças em viveiro de mudas de aceroleira. Cruz das Almas: Embrapa - CNPMF, 2008b. 2p. (Acerola em Foco, 13)

RITZINGER, R.; RITZINGER, C.H.S.P.R.; GHINI, R. Preparo de substrato para a produção de mudas de acerola. Cruz das Almas: Embrapa - CNPMF, 2003a. 2p. (Acerola em Foco, 5).

RITZINGER, R.; RITZINGER, C.H.S.P.R.Acerola.In: RODRIGUES, M.G.V.; DIAS, M.S.C. Cultivo tropical de fruteiras. Informe Agropecuário: Belo Horizonte, v.32, n.264, p.17-25, 2011.

RITZINGER, R.; SOARES FILHO, W. dos S.; OLIVEIRA, J.R.P. Variedades e melhoramento. In: RITZINGER, R.; KOBAYASHI, A. K.; OLIVEIRA, J. R. P. (Ed.). A cultura da aceroleira. Cruz das Almas: Embrapa Mandioca e Fruticultura, 2003b. p.65-72.

SALLA, M.F.S.; RUAS, C.de F.; RUAS, P.M.; CARPENTIERI-PÍPOLO, V. Uso de marcadores moleculares na análise da variabilidade genética em acerola (Malpighia emarginata D.C.). Revista Brasileira de Fruticultura, Jaboticabal, v.24, n.1, p.15-22, 2002.

SEMPIONATO, O.R.; STUCHI, E.S.; DONADIO, L.C. Viveiros de citros. Jaboticabal: FUNEP, 1997. 37p.

SIMÕES, D.; SILVA, R.B.G.; SILVA, M.R. Composição do substrato sobre o desenvolvimento, qualidade e custo de produção de mudas de Eucalyptus grandis Hill ex Maiden x Eucalyptus urophylla S. T. Blake. Ciência Florestal, Santa Maria, v.22, n.1, p.91-100, 2012.

TAVEIRA, J.A. Fibra de coco: uma nova alternativa para a formação de mudas cítricas. 2016. Disponível em: $<$ http://www.agrofit.com.br/portal/citros/52-citros/88fibra-de-coco-uma-nova-alternativa-para-formacao-demudas-citricas->. Acesso em: 14 jul. 2016. 
TOOGOOD, A. Plant propagation. New York: American Horticultural Society, 1999. 320p.

VERNIER, R.M.; CARDOSO, S.B. Influência do ácido indolbutírico no enraizamento de estacas em espécies frutíferas e ornamentais. Revista Eletrônica de Educação e Ciência, Avaré, v.3, n.2, p.11-16, 2013. 